\title{
ANALISIS STRUKTURALISME NASKAH DRAMA TARLING \\ “DOKTER PALSU" KARYA HJ. DARIYAH
}

\author{
Saroni \\ Prodi Pendidikan Bahasa dan Sastra Indonesia \\ Universitas Wiralodra \\ e-mail: inorasironi@yahoo.co.id
}

\begin{abstract}
ABSTRAK
Tarling is a musical intellectual that contributes to the uplift of Indramayu's cultural arts. According to Hidayatulla (2005) the art of tarling still exists and is developing, but its existence does not receive much attention from the community, especially the younger generation. The cultural development is emphasized by Maknum (2004: 81) the process of art development is influenced by several factors namely scientific, environmental, and time factors. All three take place interactively. As a cultural product, art in its development will be subject to the main laws that govern human development. The diversity of Tarling music that continues to change and develop in the wider community, is feared to reduce the function of identity, as well as undergoing changes in shape which ultimately is not impossible that will farther and lose its original form.

The main objective of this research is an effort in the inheritance and preservation of Indramayu culture by realizing the design of the staging of the Tarling drama script "Fake Doctor" by Hj. Dariyah by analyzing the structure of the Tarling drama script "Fake Doctor" by $\mathrm{Hj}$. Dariyah covers the analysis of themes, characterizations, and plot. The study was designed in 1 (one) year using qualitative methods. This research provides a fundamental contribution related to a field of science through the performance of the Tarling drama script "Fake Doctor" by Hj. Dariyah. First, students who are involved as drama players not only get literary theory in lectures, but students also gain experience in practicing literary science in a performance. Second, the results of this study can be used as an alternative to be staged in the tarling groups throughout Indramayu Regency. Third, the results of this study can be taken into consideration for local governments related to the cultural heritage and preservation of Indramayu.
\end{abstract}

Keywords: Analysis, drama script, tarling, culture, Indramayu. 


\begin{abstract}
ABSTRAK
Tarling merupakan karya intelektual musik yang memberikan andil mengangkat nilai seni budaya Indramayu. Menurut Hidayatulla (2005) seni tarling masih ada dan berkembang, tetapi keberadaannya kurang mendapatkan perhatian dari masyarakat terutama generasi muda. Perkembangan budaya tersebut dipertegas oleh Maknum (2004:81) proses perkembangan seni dipengaruhi oleh beberapa faktor yaitu faktor ilmiah, lingkungan, dan waktu. Ketiganya berlangsung secara interaktif. Sebagai produk kebudayaan, kesenian dalam perkembangannya akan tunduk kepada hukum-hukum utama yang mengatur perkembangan manusia. Beragamnya musik Tarling yang terus berubah dan berkembang di masyarakat luas, dikhawatirkan mengurangi fungsi identitas, serta mengalami perubahan bentuk yang akhirnya bukan mustahil akan semakin jauh dan kehilangan bentuk aslinya.

Tujuan utama penelitian ini adalah upaya dalam pewarisan dan pemertahanan budaya Indramayu dengan cara merealisasikan rancangan pementasan naskah drama tarling "Dokter Palsu" Karya Hj. Dariyah dengan menganalisi struktur naskah drama tarling "Dokter Palsu" Karya Hj. Dariyah meliputi analisis tema, penokohan, dan alur. Penelitian dirancang dalam 1 (satu) tahun menggunakan metode kualitatif. Penelitian ini memberikan kontribusi mendasar terkait suatu bidang ilmu melalui pementasan naskah drama tarling “Dokter Palsu” Karya Hj. Dariyah. Pertama, mahasiswa yang terlibat sebagai pemain drama tidak hanya mendapatkan teori sastra saja pada perkuliahan, namun mahasiswa juga memeroleh pengalaman dalam mempraktikan ilmu sastra dalam sebuah pementasan. Kedua, hasil penelitian ini dapat dijadikan alternatif untuk dipentaskan pada group tarling se-Kabupaten Indramayu. Ketiga, hasil penelitian ini dapat dijadikan bahan pertimbangan bagi pemerintah daerah terkait dengan pewarisan dan pemertahanan budaya Indramayu.
\end{abstract}

Kata kunci: Analisis, naskah drama, tarling, budaya, Indramayu.

\section{PENDAHULUAN}

Tarling merupakan karya intelektual musik yang memberikan andil mengangkat nilai-nilai seni budaya Indramayu. Beragamnya musik tarling yang terus berubah dan berkembang pada masyarakat, dikhawatirkan mengurangi fungsi identitas, serta mengalami perubahan bentuk yang akhirnya akan semakin jauh dan kehilangan bentuk aslinya. Menurut Hidayatulla (2005) seni tarling masih ada dan berkembang, tetapi keberadaannya kurang mendapatkan perhatian dari masyarakat terutama generasi muda. Penelitian ini sebagai upaya dalam pewarisan dan pemertahanan budaya
Indramayu. Perkembangan budaya tersebut dipertegas oleh Maknum (2004:81) proses perkembangan seni dipengaruhi oleh beberapa faktor yaitu faktor ilmiah, lingkungan, dan waktu. Ketiganya berlangsung secara interaktif. Sebagai produk kebudayaan, kesenian dalam perkembangannya akan tunduk kepada hukum-hukum utama yang mengatur perkembangan manusia.

Fakta yang ditemukan di lapangan menunjukkan bahwa pementasan drama tarling jarang sekali ditemukan. Drama tarling dangdut yang biasa ada pada masyarakat diawali dengan lagu-lagu tarling yang 
dibawakan oleh para seniman dangdut yang kemudian dilanjutkan mimbar drama tarling pada pukul 00.00 dini hari.Masyarakat lebih tertarik pada lagu-lagu tarling dibandingkan dengan dramanya sehingga masyarakat berbondong-bondong pulang tanpa menonton pagelaran dramanya.Sehubungan dengan hal tersebut, penelitian ini merupakan satu upaya untuk pewarisan dan pemertahananbudaya Indramayu, khususnya tarling, sehingga diharapkan dapat menyelamatkan satu aset budaya nasional.Selain fakta-fakta di atas, beberapa fakta lain juga menyebutkan hal yang sama. Menurut (Kasim, 2002: 74) jika hal ini terus berlangsung, jangan salahkan kalau tarling hanya bisa didengar dari kasetkaset bulukan.Kemudian melenceng menjadi lebih dikenal lewat lagu-lagunya saja.Berdasarkan hasil observasi, beberapa upaya yangsudah dilakukan untuk melestarikan tarling diantaranya: 1)melakukan seminar rutin seperti "Revitalisasi Kesenian Tarling" di desa Mertasinga kabupaten Cirebon, 2) melakukan pelatihan musik tarling dengan menggunakan metode tradisional 3)mempromosikan kebudayaan Indramayu-Cirebon termasuk musik tarling dengan membuat Talk Show SAMBEL TRASI (Sambil Belajar Tradisi) di Cirebon TV.

Beberapa upaya yang disebutkan di atas belum ada suatu kegiatan pementasan naskah drama tarling sebagai upaya pewarisan dan pemertahanan budaya Indramayu. Oleh karena itu, dalam penelitian ini merancang suatu kualitas dan kelayakan sebuah pementasan. Naskah drama tarling menjadi hal yang sangat penting dalam pementasan yang berkualitas dan layak tersebut. Peneliti memilih naskah drama tarling "Dokter Palsu" Karya Hj. Dariyah untuk dipentaskan. Cerita drama tarling "Dokter Palsu" Karya Hj. Dariyah termasuk ke dalam komedi tragedi.Cerita ini bermula dari sepasang kekasih yang tidak mendapat restu dari kedua orang tua, sehingga ingin bertemu pun gadis itu berpura-pura sakit agar bisa izin keluar rumah dengan alasan periksa ke dokter. Namun yang dilakukan gadis itu bukan menemui dokter tetapi bertemu dengan kekasihnya.Orang tuanya curiga dan mengikuti ke mana gadis itu pergi, akhirnya kepergoklah mereka sedang berpacaran.Kegelisahan gadis itu karena ketahuan telah berbohong tidak membuat gadis itu berhenti berbohong, justru malah melanjutkan cerita kebohongannya itu, bahwa pria yang ditemuinya dipinggir jalan itu adalah seorang dokter. Naskah drama tersebut memiliki nilai-nilai moral dan budaya yang sangat tinggi yang diangkat dari kehidupan sehari-hari, khususnya pada masyarakat Indramayu. Cerita tersebut memiliki kekhasan dalam penyampaian ceritanya yaitu dalam berdialog menggunakan lagu-lagu 
yang diiringi dengan gamelan musik gitar dan suling yang kemudian disebut dengan tarling.

Mementaskan naskah drama tarling "Dokter Palsu" Karya Hj. Dariyah membutuhkan konsep yang kreatif. Konsep yang kreatif tersebut tercipta dalam sebuah rancangan. Rancangan tersebut di antaranya: 1) analisis struktur naskah drama tarling "Dokter Palsu" karya Hj. Dariyah meliputi analisis tema, penokohan, alur, dan latar peristiwa; 2) pemilihan pemain yang memiliki kedisiplinan dan kesungguhan dalam menjalani proses pementasan; 3) melakukan pelatihan pemain melalui latihan-latihan dasar dan latihan teknik seperti olah tubuh, olah vokal, dan olah rasa; 4) merancang gambar panggung menyangkut seluruh aspek visual yang dapat ditangkap oleh penonton baik itu blocking, movement, dan centre of interest, maupun tata pentas, musik, busana, rias, dan cahaya; 5) mementaskan naskah drama tarling "Dokter Palsu" karya $\mathrm{Hj}$. Dariyah yang menarik, berkualitas, dan layak untuk ditonton.

Penelitian ini memberikan kontribusi mendasar terkait suatu bidang ilmu melalui pementasan naskah drama tarling "Dokter Palsu" Karya Hj. Dariyah. Pertama, mahasiswa yang terlibat sebagai pemain drama tidak hanya mendapatkan teori sastra saja pada perkuliahan, namun mahasiswa juga memeroleh pengalaman dalam mempraktikan ilmu sastra dalam sebuah pementasan. Kedua, hasil penelitian ini dapat dijadikan alternatif untuk dipentaskan pada group tarling seKabupaten Indramayu. Ketiga, hasil penelitian ini dapat dijadikan bahan pertimbangan bagi pemerintah daerah terkait dengan pewarisan dan pemertahanan budaya Indramayu. Caranya yaitu melakukan kerjasama dengan Dinas Kebudayaan dan Pariwisata Kabupaten Indramayu untuk mengadakan pementasan rutin mahasiswa sanggar sastra di taman kota Indramayu. Selain memberikan kontribusi terkait suatu bidang ilmu, luaran dari penelitian ini adalah publikasi ilmiah dimuat dalam jurnal nasional tidak terakreditasi, pementasan karya seni, bahan ajar mata kuliah Sanggar Sastra mengenai transformasi naskah drama ke dalam bentuk pementasan, dan bahan ajar mata kuliah Apresiasi Drama Indonesia mengenai rancangan dari sebuah naskah untuk dipentaskan.

\section{KERANGKA TEORI}

\section{Landasan Teori}

\section{Seni Budaya Tarling}

Faruk dalam Kongres Bahasa Cirebon (2007) mengatakan bahwa masyarakat Cirebon adalah masyarakat yang secara geokultural hidup di wilayah perbatasan antara dua budaya, yaitu budaya Jawa dan budaya Sunda.Munculnya seni tarling di daerah Indramayu-Cirebon merupakan 
kekayaan kearifan budaya daerah.Kearifan budaya adalah fungsi dan nilai-nilai budaya yang menonjol dan memiliki kemampuan (daya pukau) yang luar biasa cerdas dalam memecahkan persoalan hidup (Santosa, 2011:7).Seni tarling bukan hanya menonjolkan pada kegiatan drama, namun juga pada lagu bahasa jawa dalam pementasannya. Seperti halnya diungkapkan Sulistijo, dkk, 2001:XIII-IX) dalam laras, suasana lagu, tema drama, maupun bahasa pengantarnya yaitu bahasa Jawa dengan dialek Dermayon-Cerbon. Sedangkan menurut Soemardjo (2010: 158) tarling merupakan sastra lisan dalam bentuk penuturan cerita legenda atau babad.

Masyarakat Indramayu memberikan nama kesenian budaya dengan nama tarling dengan tujuan untuk mempertahankan kesan campurannya. Gitar dan suling adalah dua dunia yang berbeda, yang satu bersifat familiar dengan masyarakat setempat, sedangkan yang satu lagi mengandung konotasi asing atau Barat.Tarling adalah salah satu seni tradisi yang sangat khas dan terkenal dari daerah Cirebon dan Indramayu.Nama tarling diambil dari singkatan dua alat musik dominan, yaitu gitar (akustik) dan suling.Selain kedua instrumen ini, terdapat pula sejumlah perkusi, saron, kempul, dan gong.Nama dan alat-alat musik yang dipergunakan sudah menunjukkan bahwa sesungguhnya tarling lebih condong pada seni tradisi dalam genre musik.Namun, jika disimak lebih jauh meskipun termasuk genre musik, tarling dapat dikatakan mengandung seni sastra.Hal itu dapat diketahui dari liriklirik lagu yang dibawakan dan dari drama yang disajikan selama pertujukan tarling berlangsung.Menurut (Saptono, 2013:23) Tarling merupakan kependekan dari kata 'gitar' dan 'suling', namun tarling juga memliki filsafah 'yes wis mlatar, kudu eling' Jika berbuat negative harus segera sadar dan bertobat.

Tarling juga merupakan genre sastra berbentuk puisi. Sebagaimana dikatakan oleh Riffatere dalam Suratno (2005) bahwa puisi adalah ekspresi tidak langsung yang menyatakan sesuatu dengan maksud lain. Ekspresi tidak langsung dalam puisi itu tampak dalam penggantian arti, penyimpangan arti, dan penciptaan arti. Penggantian arti terwujud dalam penggunaan metafora dan majasmajas lainnya. Penyimpangan arti disebabkan oleh ambiguitas atau makna ganda, dan kontradiksi. Penciptaan arti adanya konvensi kepuitisan yang berupa bentuk visual secara linguistik, seperti pembaitan, enjambement, persajakan, dan tipografis.Kategori ekspresi tidak langsung seperti yang telah dipaparkan tersebut terdapat pada teks tarling karena di dalam teks tarling mengandung peribahasa (ungkapan), wangsalan, parikan, ambiguitas, 
pengaturan bunyi akhir, tipografi, dan pengaturan bait.

Kesenian tarling diperkirakan lahir pada masa-masa perang kemerdekaan melawan pendudukan Jepang. Sepanjang malam semasa istirahat di sela-sela pertempuran mengalunlah lagu-lagu karawitan dengan instrumen gitar. Dua orang bermain gitar sebagai pengiring dan melodi serta yang lain sebagai penyanyi. Perkembangan selanjutnya menunjukkan perubahan dalam personal, misalnya instrumen ditambah dengan gong, gendang, dan tutukan (dua buah bonang berukuran besar dan kecilyang berfungsi sebagai pengatur irama). Lagu-lagu tarling awalnya berupa parikan dan wangsalan yang disambung-sambung oleh sinden menjadi sebuah rangkaian lagu. Lirik lagu itu berisi ungkapan hati penyanyi dalam melakonkan sebuah cerita dalam bentuk monolog. Pada waktu-waktu berikutnya cerita diungkapkan dalam bentuk dialog antara sinden dan pelaku tarling lainnya berdasarkan tema cerita yang disampaikan.

Berkaitan dengan tema, Kasim (2002) menyatakan bahwa tema-tema tentang romantika kehidupan rumah tangga menjadi tema-tema yang banyak yang diciptakan musisi tarling. Tarling dipertunjukan sematamata mengandalkan improvisasi. Pada saat tampil, seniman tarling tidak berbekal teks lagu dan tidak ada cerita khusus yang akan disampaikan pada penonton. Namun, dalam penyampaiannya menjadi salah satu ciri khas tarling, pelaku tarling menggunakan dua gaya, yakni gaya parikan dan wangsalan, yang termasuk genre sastra, khususnya puisi. Sebagaimana diketahui parikan dan wangsalan adalah dua jenis puisi lama. Parikan adalah puisi berirama (murwakanti) yang terdiri atas dua atau empat baris. Jika larik dalam parikan terdiri atas dua baris disebut parikan tunggal, sedangkan yang empat baris disebut dengan parikan rangkap, misalnya apa kawat apa tali/lamun kawat disambung-sambung/apa niat apa bli/lamun niat aja tanggung-tanggung/. Sedangkan wangsalan merupakan serangkaian kalimat yang merujuk pada satu makna. Dalam peristilahan modern, wangsalan disebut sebagai rhyming slang, mirip dengan tekateki atau badekan, misalnya ireng-ireng ning rerangkeng memiliki makna 'sawang', atau gelang alit mungging jriji yang bermakna 'cincin'.

\section{Naskah Drama}

Keberadaan naskah drama sangatlah penting karena, sebelum drama dipentaskanmemerlukan adanya sebuah naskah. Menurut Suroso (2015:21) drama sebagai teater adalah pengolahan naskah drama oleh sutradara untuk dipentaskan. Arahan sutradara dipelajari dan ditafsirkan oleh aktor ke sejumlah penonton. Dalam 
hubungannya dengan penonton, ia memiliki tafsir sendiri terhadap apa yang dilakukan oleh aktor. Dengan demikian, ketika sebuah naskah dipentaskan ke sejumlah penonton dengan tafsir sutradara, aktor, dan tim artistik, naskah tersebut sudah menjelma sebabagai karya teater, sedangkan menurut (Hansanudin, 2009: 42) para penulis referensi sebelumnya kebanyakan sepakat untuk menyebutkan bahwa naskah drama Bebasari yang diterbitkan pada tahun 1926 hasil karya Roestam Effendi sebagai naskah drama pertama di Indonesia.

Selain peran dan peranan teks samping itu penting, ada beberapa istilah lagi yang perlu dipahami artinya. Istilah-istilah ini masih di seputar seluk beluk drama di antaranya adalah: 1) skenario yaitu naskah drama yang sudah dilengkapi dengan petunjuk pementasannya; 2) sutradara yaituorang yang mengatur atau mengarahkan cara-cara memperagakan atau mempertunjukkan drama dihadapan penonton; 3) aktor yaitupemain drama (pria); 4) aktris yaitu pemain drama (wanita); 5) acting yaitu teknik bermain; 6) casting yaituteknik pemilihan (peran) pemain (aktor ataupun aktris); 7) babak yaitu bagian-bagian suatu lakon atau cerita drama; 8) adegan yaitu bagian dari babak yang berisi gambaran atau lukisan suatu situasi atau kejadian; 9)properti yaitu susunan benda-benda perlengkapan suatu pertunjukan; 10) blocking yaitu batas ruang gerak setiap pemain atau pelaku dalam suatu pementasan. Sedangkan menurut Waluyo (2001: 6-30) struktur drama terdiri dari (1) penokohan dan perwatakan, (2) plot atau kerangka cerita, (3) dialog (percakapan), (4) setting/landasan/tempat kejadian, (5) tema/nada dasar cerita, (6) amanat, (7) petunjuk teknis, dan (8) drama sebagai interpretasi kehidupan.Berbeda dengan Waluyo (2003:178) yang diperhatikan dalam penampilan memerankan suatu tokoh yaitu acting yang lebih di titikberatkan pada penghayatan tepat, dialog suara yang tepat, dan ekspresi.Sedangkan dalam Dekdikbud (2006) siswa dituntut melakukan dalam hal pelafalan, intonasi, mimik, kinesik, penghayatan, dan kompak.

\section{METODE PENELITIAN}

Metode yang digunakan dalam penelitian ini adalah metode kualitatif. Penelitian kualitatif memerlukan ketajaman analisis, objektivitas, sistematik, dan sistemik, sehingga diperoleh ketepatan dalam menginterpretasi data. Menurut (Sugiyono, 2013: 27) peneliti kualitatif belum memiliki masalah, atau keinginan yang jelas, tetapi dapat langsung memasuki objek/lapangan. Pada waktu memasuki objek, peneliti tentu merasa asing terhadap pertunjukkan wayang kulit. Setelah memasuki objek, peneliti kualitatif akan melihat segala sesuatu yang ada di tempat itu, yang masih bersifat umum. 
Melalui metode ini peneliti mengamati, menganalisis, dan mendeskripsikan naskah drama tarling "Dokter Palsu" karya $\mathrm{Hj}$. Dariyah dengan menggunakan metode penyutradaraan. Penelitian ini, peneliti menggabungkan dua metode penyutradaraan, yakni menurut Gordon Craig dan Laissez Faire. Gordon Craig menempatkan sutradara sebagai pusat penciptaan, sedangkan aktor dan aktris sebagai alat mewujudkan gagasan sutradara. Sementara itu, Laissez Faire mengunggkapkan bahwa aktor dan aktris adalah pusat penciptaan. Tugas sutradara adalah membantu aktor dan aktris mengekspresikan dirinya dalam naskah, dan para aktor dan aktris bebas mengembangkan konsepsi individualnya agar melaksanakan peranan sebaik-baiknya (Harymawan, 1988: $65)$.

\section{HASIL DAN PEMBAHASAN}

\section{Struktur Naskah Drama Tarling “Dokter Palsu" Karya Hj. Dariyah}

\section{Analisis Tema}

Naskah Drama Tarling "Dokter

Palsu" memiliki tema tentang percintaan anak remaja yang tidak mendapat restu dari orang tuanya. Tema percintaan yang tidak direstui oleh orang tua ini memang sudah lama ada sejak naskah drama ini ditulis pada tahun 80an. Hal tersebut dibuktikan pada penggalan dari naskah drama berikut.

$$
\text { Yoyo : :'Iin...." }
$$

Iin : "Kang Yoyo sing
mau tah kang?",

Yoyo :"Sing wingi"

Iin :"Maaf kulane

nembek teka ya kang"

Yoyo : :"Iin sih nangapa,

janjine jam sanga sampe jam

sepuluh

nembek teka"

Iin :"Maaf kang

Yoyo,bisane kula telat,kang Yoyo

kudu weruh

kang baka kula kih

lunga-lunga tanpa tujuan diblolihi ning mimi"

Yoyo :"Oooh dadi baka

lunga-lunga tanpa tujuan dilarang ning

wong tua"
Iin :"Selalu dilarang

kang Yoyo" (Babak 3, adegan 1)

Tema pada cerita ini meskipun tidak direstui oleh kedua orang tuanya tetapi tidak serius dalam mengemas cerita dan tidak menegangkan. Kebalikannya, cerita ini justru dikemas secara unik, jenaka, dan tidak kaku. Sehingga terkesan lucu dan menggemaskan. Hal tersebut dibuktikan pada penggalan dari naskah drama berikut.

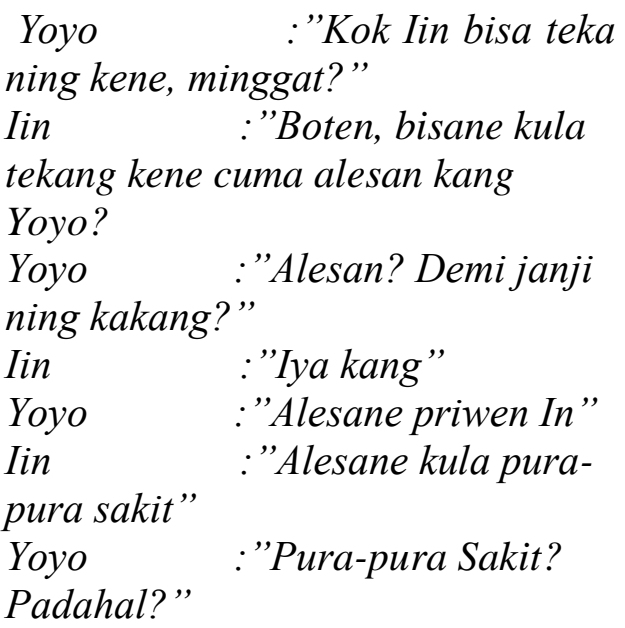


Iin :"Padahal sih

bohongan"

Yoyo :"Paingan kakang kuh

In uripe kurang bahagia, senajan

sing demen ning

kakang pirang-pirang tapi cinta

kakang

mung ning Iin,

maune mah kakang arep balik

maning"

\section{Analisis Penokohan}

(Babak 3, adegan 1)

Naskah Drama Tarling "Dokter

Palsu" terdapat enam tokoh, di antaranya yaitu Yoyo, Hj. Dariyah, Iin, Juniah,

Bapaknya Yoyo, dan Mang Oglek.

Tokoh tersebut berdasarkan pada namanama yang terdapat pada naskah drama yang kemudian dipentaskan.

\section{1) Hasil Analisis Tokoh Yoyo}

Tokoh Yoyo merupakan salah satu tokoh utama dalam cerita ini. Dia tokoh yang unik dan jenaka. Pandai merayu melalui lagu-lagu yang dinyanyikannya. Hal tersebut dibuktikan pada penggalan dari naskah drama berikut.

\section{Yoyo :"Paingan}

kakang kuh In uripe kurang bahagia, senajan sing demen ning kakang pirang-pirang tapi cinta kakang mung ning Iin, maune

mah kakang arep balik maning" (Babak 3, adegan 1)
Karakterisitik laki-laki yang setia dengan pasangannya. Bahkan, ketika lin terlambat datang pada saat pertemuan, Yoyo masih tetap setia menunggunya. Hal tersebut dibuktikan pada penggalan dari naskah drama berikut.

$\begin{array}{ll}\text { Yoyo } & : \text { "Iin...." } \\ \text { Iin } & : \text { "Kang Yoyo sing mau } \\ \text { tah kang?" } & \\ \text { Yoyo } & : \text { "Sing wingi", } \\ \text { Iin } & : \text { "Maaf kulane nembek } \\ \text { teka ya kang," } & \\ \text { Yoyo } \quad \text { "Iin sih nangapa, }\end{array}$
janjine jam sanga sampe jam sepuluh nembek teka"

Iin :"Maaf kang

Yoyo,bisane kula telat,kang Yoyo kudu

weruh kang baka kula

kih lunga-lunga tanpa tujuan

(Babak 3, adegan 1) diblolihi ning mimi"

Kesetiaan Yoyo pun terlihat ketika dia dilarang oleh Bapaknya untuk menemui Iin tetapi dia tetap berusaha meyakinkan Bapaknya bahwa dia telah berjanji akan menemui Iin. Usaha menyakinkan itu terbukti pada kutipan berikut.

Yoyo : :Soale pa janji iku utang,baka janji ora ditepati pada bae due utang" Juniah :"Iya ningan yaa" Yoyo asik," Kulane kan garep 


Juniah :"Wis
jage mangkat aja
ngeladeni Bapane ira",

(Babak 1, adegan 2)

\section{2) Hasil Analisis Tokoh Hj. Dariyah}

Tokoh Hj. Dariyah merupakan tokoh yang paling kuat dalam cerita ini, karena berawal dari tokoh ini lah semua permasalahan bermunculan. Tidak setuju anaknya didekati oleh banyak pemuda terlebih pemuda yang miskin dan tidak punya pekerjaan. Hal tersebut dibuktikan pada penggalan dari naskah drama berikut.

Dariyah :"Ampun....sangalikur , tingeling ampun kita wong due Anak wadon kuh kaya kenen apa? Bener jare wong kandah ya anak-anak, enek-enek, enik-enik, enuk-enuk, nyiksa, nukari, nekek ning wong tua, sira kih kenang apa sih ngelamun bae lagi mikiri apa sih? Kien kih bekas tegesane sapa, roko sapa

ntas kanda

karo sapa? Pemuda ya mene ya?

Iin :"Boten mi"
Dariyah : :'Ira mah ora kena diadol mahal sih, pengene di obral nabae ora kena di eman ora kena di sayang, ora kena diadol larang” Iin :"Sanes mi Dariyah :"Kosi tapake gede-gede temen kinih, kita sing terus terang bli sudi dunia akherat due anak wadon tak eluselus, besuk gede nganggo modale wong tua, Iin"

Iin :"Kula mi" Dariyah :"Kita ngerti, setindak lakune sira ngerti, tak titeni bae, mene sing parek kita arep ngomong" Iin :"Aja sewot mi"

Dariyah : :"Ari wong tua kloyong sedelet, nerima pemuda, wong tua lunga, nerima wong lanang sing langka duite"

$$
\text { adegan 2) }
$$

(Babak 2,

Tidak hanya sampai disitu, tokoh $\mathrm{Hj}$. Dariyah pun bukan hanya tidak merestui hubungan antara Iin dengan Yoyo, tetapi tokoh ini juga telah menyiapkan calon untuk menjadi menantunya yaitu orang kaya. Hal tersebut dibuktikan pada 
penggalan dari naskah drama

berikut.

\section{Dariyah :"Wis aja} jawab, aja cerita, eh dasar pinter sandiwara, ari mau ana sapa, pacar ira bocah brandalan desa",

Iin :"Duh aduh

mimi, salah taksir, kari mau sih kader wong mampir, mimi aja padu ngomong, kula isin bokat

krungu ning uwong" Dariyah :"Sebabe mimi kuatir, bokatan ora kepikir sebabe

dunya sing dihargani" zaman saiki Iin :"Kula kuh uwis ngarti kang dimaksud ning mimi, kon luruh laki sugih bagen wonge gelis mati" adegan 2)

(Babak 2,

\section{3) Hasil Analisis Tokoh Iin}

Tokok Iin merupakan tokoh utama dalam cerita ini. Gadis cantik yang menjadi sorotan banyak pemuda. Karena kecantikannya itu banyak para pemuda yang naksir. Hal ini menjadi sesuatu yang merugikan bagi $\mathrm{Hj}$. Dariyah karena dia menginginkan anaknya itu dinikahi oleh orang kaya tidak peduli orang itu sudah tua yang penting banyak harta. Namun Iin tidak kehabisan akal dia berpura-pura sakit untuk bisa izin keluar menemui pacarnya yang bernama Yoyo. Hal tersebut dibuktikan pada penggalan dari naskah drama berikut.

Dariyah :"Iin, sebenere
sira ngelamun bae
kenangapa coba,

Iin ngomong!" sebenere kula lagi sakit mimi, endase puyeng, Awak atis, wetenge mlilit mi" Dariyah :"Nangapa sira bli ngomong sing maumau? Ari wong sakit kuh gage diobati nok ari masih pengen urip mah kalesan, dilalu laman lamun laman lamun bli seneng deleng wong enom ngelamun kuh, mana suntik gagean

luruh dokter, prangsane mah diendakaken bakali waras tah, luruh dokter mana kah suntik!" Iin :"Duite sih $m i "$

Dariyah :"Ya duite ya ana, ceg rongewu kih, olih adol beras mau"

Iin :"Mangsa rongewu sih mi, bli cukup mi"

Dariyah :"Eh pira sih pira, mimi gah lagi wingi priksa ning 


\section{puskesmas \\ kuh mung Pitungatus, seobate, kloyong gagean aja

Bentuk pemberontakan tokoh Iin terhadap Ibunya pun nampak dalam cerita ini. Iin berontak dan berusaha untuk melawan Ibunya yang selalu ingin menikahkan lin dengan orang kaya. Hal tersebut dibuktikan pada penggalan dari naskah drama berikut.

Dariyah :"Wis pirang balen ngomongi, pura-pura bli ngerti,

pancene sira sengaja ora nurut ning wong tua"

Iin :"Dih idih mimi kok nyewot, cangkem ngomel mata mlotot apa sih salahe kula mimi kok naek darah"
Dariyah :"Wis aja jawab, aja cerita, eh dasar pinter sandiwara, ari mau ana sapa, pacar ira bocah brandalan desa" Iin :"Duh aduh mimi, salah taksir, kari mau sih kader wong
mampir, mimi aja padu ngomong, kula isin bokat krungu ning uwong" Dariyah :"Sebabe mimi kuatir, bokatan ora kepikir sebabe zaman saiki dunya sing dihargani" Iin :"Kula kuh uwis ngarti kang dimaksud ning mimi, kon

luruh laki sugih bagen wonge gelis mati"

(Babak 2,

adegan 2).

\section{4) Hasil Analisis Tokoh Juniah}

Tokoh Juniah pada cerita ini berperan sebagai pendukung Yoyo. Dia adalah Ibunya Yoyo yang mendukung dengan keinginan Yoyo yang berpacaran dengan Iin. Meskipun dia ditentang oleh suaminya yang tidak setuju tetapi, Juniah tetap mendukung karena sejatinya cinta mamang harus diperjuangkan. Hal tersebut 
dibuktikan pada penggalan dari naskah drama berikut.

$$
\text { Juniah : :Ya }
$$

durung tentu, durung tentu baranganu jeh

nasibe anake bagus aduh kang, enak wong due

besan

sugih kuh paribasane kayu mati mrembet

ning

kayu urip, bokat bae bisa sambung

$$
\begin{aligned}
& \text { sinyambungan" } \\
& \text { Bapak } \\
& \text { :"Mbuh gah kita gah } \\
& \text { beli setuju, langka sing } \\
& \text { endi- }
\end{aligned}
$$$$
\text { endi }
$$

gah wong sugih due mantu ning wong mlarat

kuh"

Juniah :"Soten

jare sampeyan, eh kang aja lok ngalang-

ngalangi kemauane wong enom, sejen wong bengen

bari jaman sekien sejen, bengen tah kita masih

enom lagi masih bocah nurut ning

omogane wong tua jaman sekien mah kualik wong tua sing nurut ning wong enom, sampean mah

delengna bae endah temen kader gah wong lanang arep ngalor arep ngidu, sing penting

\section{5) Hasil Analisis Tokoh Bapaknya Yoyo}

Tokoh Bapaknya Yoyo ini berbanding terbalik dengan karakter Juniah. Dia orang yang paling tidak setuju dengan percintaan antara Yoyo dan Iin karena silsilah keluarnya Yoyo dan Iin yang sangat jauh berbeda. Hal tersebut dibuktikan pada penggalan dari naskah drama berikut.

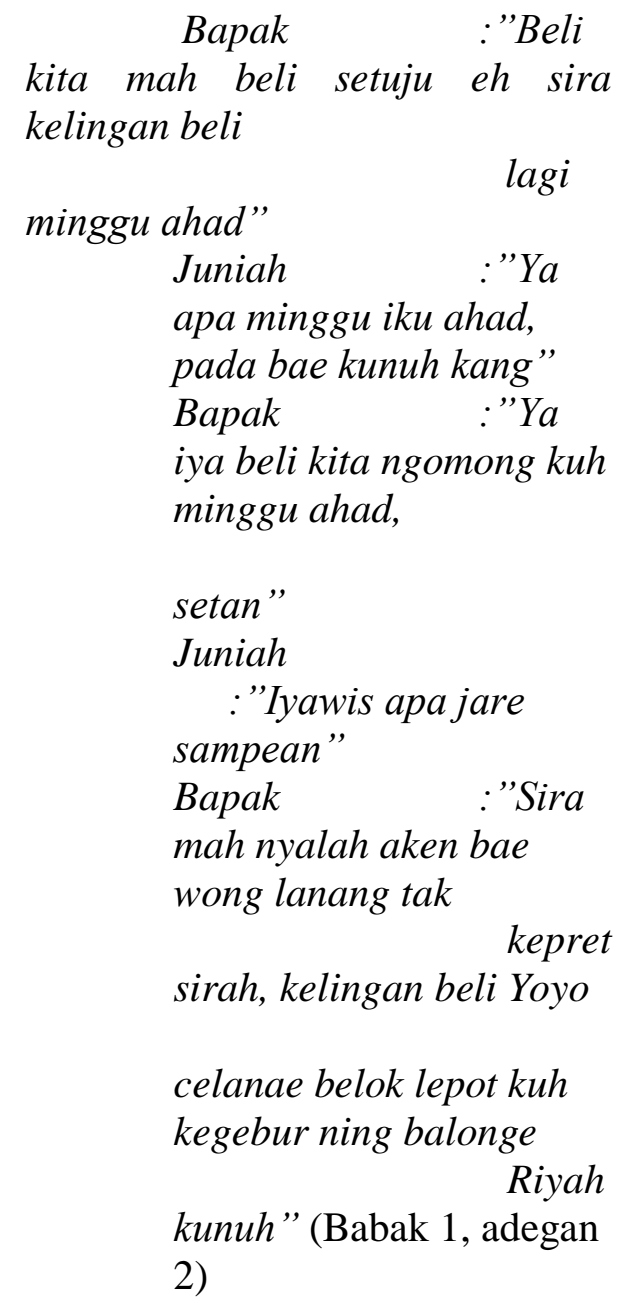

6) Hasil Analisis Tokoh Mang Oglek 
Tokoh Oglek ini sebagai pelengkap. Kehadiran tokoh Oglek menjadi pemanis dan penghibur, karena setiap dialognya menimbulkan gelak tawa. Hal tersebut dibuktikan pada penggalan dari naskah drama berikut.

$$
\text { Oglek : :Dudu wong }
$$
cilik-cilik, bandar baka calon lakine Iin

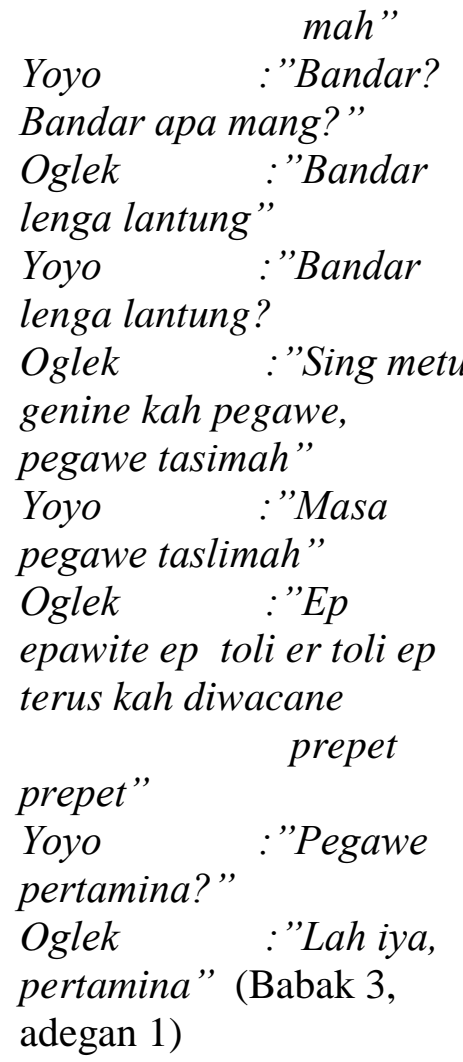

\section{Analisis Alur}

Alur dalam naskah drama tarling "Dokter Palsu” karya Hj. Dariyah dibagi menjadi empat bagian yaitu perkenalan, konflik, klimaks,dan penyelesaian. Pembagian tersebut berdasarkan pada teori Cohen (2010:33) yang menjabarkan bahwa pengamalan dramatik setidaknya dibagi menjadi empat yaitu exposition (perkenalan), conflict (permasalahan), climax (puncak permasalahan), denouement (penyelesaian).

\section{1) Hasil Analisis Tahap Perkenalan}

Tahap exposition (perkenalan) adalah tahapan pertama dalam alur cerita. Unsur-unsur dasar cerita seperti tokoh, latar tempat, waktu, dan suasana dihadirkan pada tahap ini. Dengan begitu, pembaca atau penonton dapat mengetahui siapa saja yang menjadi tokoh sebuah cerita, di mana dan kapan cerita itu berlangsung, serta suasana apa yang hendak dibangun oleh pengarang di dalam cerita itu. Tahap exposition (perkenalan) bermula ketika Yoyo mendapatkan surat cinta dari Iin, hal itu terdapat pada lirik lagu yang dinyanyikan oleh Yoyo. Hal tersebut dibuktikan pada penggalan dari naskah drama berikut.

degan

"Dag dig dug ati rasa deg

Yen nrima surat sing demenan

Terus digawa ning tempat sepi-sepine Jage dibaca pengen weruh isine

Aduh sayang, aduh manis Pikir melayang setengah nangis

Dag dig dug ati rasa deg degan.....

Aduh seneng pisan bungah bli kejagan

Arep jalan-jalan karo demenan 
Tek rangkul pundake tek ciwit janggute

Rambut tek beresi lambe tek nikmati

Dih idih kita kok kaya wong nglamun

Nembek surate ati kuh kaya keyungyun

Apa maning lamun karo buktine

Rasa bungah tentu langka padane

Aduh ngenes pikire rumit Kantonge kempes bli due duit" (Babak 1, adegan 1)

Tahap ini berlanjut ketika Yoyo meletakan surat cinta tersebut di atas meja, sehingga surat itu dibaca oleh kedua orang tuanya, yang akhirnya timbul permasalahan karena Bapaknya Yoyo tidak menyetujuinya. Hal tersebut dibuktikan pada penggalan dari naskah drama berikut.

Juniah

:"Biyang kun lagi apa talang teleng, biang kosi

beber-beber surat, eh kertas apa kunuh surat

kunuh?"

$$
\text { apa }
$$

Bapak

:"Kertas apa surat apa bae, ira mah beli weruh

surat dakene Yoyo, kah bocahe kah lagi

adus

kah"

Juniah

:"Yoyo? surat sing sapa jeh?
Bapak :"Surat sing sapa, ya surat sing demenane"

Juniah :"Biyang sing bener gah kang" (Babak 1, adegan 2)

\section{2) Hasil Analisis Tahap Konflik}

Tahap conflict (permasalahan) merupakan tahap munculnya konflik dalam cerita. Konflik biasanya muncul dari pertentangan antar tokoh, atau si tokoh utama mengalami masalah yang tidak diduga. Dengan adanya tahap ini, pembaca atau penonton akan mengetahui konflik apa yang akan dialami tokoh selama cerita berlangsung. Tahap ini kemudian akan mengantarkan pembaca atau penonton menuju tahap selanjutnya yang lebih rumit dan menegangkan. Peralihan dari tahap perkenalan kemudian bermunculan konflik. Pertama, konflik ketika Bapaknya Yoyo mengetahui hubungan antara Yoyo dan Iin. Hal tersebut dibuktikan pada penggalan dari naskah drama berikut.

\section{Bapak}

:"Mbuh gah kita gah beli setuju, langka sing endi-

endi gah wong sugih due mantu ning wong $k u h "$ mlarat

Juniah :"Soten jare sampeyan, eh kang aja lok ngalang-

ngalangi kemauane wong enom, sejen wong 
bengen bari jaman sekien sejen, bengen tah kita masih

enom lagi masih bocah nurut ning

omogane wong tua jaman sekien mah kualik wong tua sing nurut ning wong enom,

sampean mah delengna bae endah temen kader gah

wong

lanang arep ngalor arep ngidu, sing penting

dika

mah esuk-esuk

dahar"(Babak 1, adegan 2)

Kedua, ketika $\mathrm{Hj}$. Dariyah memergoki lin sedang menerima tamu (Mang Oglek) yang dikira adalah pemuda brandalan. Tahap ini menambah konflik yang akhirnya $\mathrm{Hj}$. Dariyah melarang Iin untukbergaul dengan pemuda siapa pun kecuali pilihannya $\mathrm{Hj}$. Dariyah sendiri. Hal tersebut dibuktikan pada penggalan dari naskah drama berikut.

$$
\begin{aligned}
& \text { Iin : "Kula mi" } \\
& \text { Dariyah: "Ampun....sangalikur, } \\
& \text { tingeling ampun kita wong due } \\
& \text { anak wadon kuh kaya } \\
& \text { kenen apa? Bener jare wong } \\
& \text { kandah ya anak-anak, } \\
& \text { enek-enek, enik-enik, enuk-enuk, } \\
& \text { nyiksa, nukari, nekek } \\
& \text { ning wong tua, sira kih kenang apa } \\
& \text { sih ngelamun bae lagi }
\end{aligned}
$$

mikiri apa sih? Kien kih bekas

tegesane sapa, roko sapa

ntas kanda

karo sapa? Pemuda ya mene ya?

Iin :"Boten mi"

Dariyah : "Ira mah ora

kena diadol mahal sih,

pengene di obral

na bae ora

kena dieman ora kena di sayang, ora kena

diadol

larang”

Iin :"Sanes mi

Dariyah :"Kosi tapake

gede-gede temen kinih, kita sing terus

terang bli sudi

dunia akherat due anak wadon tak elus-

elus, besuk

gede nganggo modale

wong tua, Iin"

Iin :"Kula mi"

Dariyah :"Kita ngerti, setindak lakune sira ngerti, tak titeni bae,

mene sing

parek kita arep ngomong"

Iin :"Aja sewot

$m i "$

Dariyah :"Ari wong tua kloyong sedelet, nerima pemuda, wong

tua lunga, nerima wong lanang sing langka duite",

Iin : "Mi, kaen kah dudu pemuda, kaen mang Oglek mi, mung

cuma

mampir"

Dariyah :"Alesan!!!"

Dariyah :"Apa sih ari

diundang ning wong tua prangkat prungkut, 
akal bulus, tiap kita lunga pasti ana pemuda, tiap wong tua langka ning umah pasti ana wonglanang, sira sih bli pengen diobral larang Iin pengene diobral mudrah bae, ana sing seneng ning sira kuh Iin wonge sugih, sugih banget, bli pengen dadi wong sugih apa?"

Iin :"Sugih

kanggo apa mi kari wonge wis tua kulan bli

Seneng

$m i$ '(Babak 2, adegan 2)

\section{3) Hasil Analisis Tahap klimaks}

Tahap climax (puncak permasalahan) adalah permasalahan yang sudah diperkenalkan di tahap sebelumnya kemudian memuncak di tahap ini. Hal itu membuat sang tokoh mengalami ketegangan dan kesulitan dalam menghadapi konflik yang dia hadapi. Akibatnya, pembaca atau penonton pun menjadi ikut tegang menyimak cerita yang disajikan kepada mereka. Tahap ini berawal Hj. Dariyan memergoki Yoyo dengan Iin sedang berpacaran di pinggir jalan. Hal tersebut dibuktikan pada penggalan dari naskah drama berikut.

Dariyah :"Eeeehhh kurang ajar! Aduh aduh ampun gusti ampun sangalikur, terlalu ya sira nok,masih cilik wis pinter nipu wong tua,ngakune lagi lara ngakune lagi sakit, ehh malah lagi demenan ning kebon sabrang, kurang ajar, sapa kiene, pemuda sapa kien, eh pemuda, maning maning bokat arep luruh pasangan deleng-deleng dikit, Iin Tarminih kuh anake wong sugih, dudu wong wadon sembarang, sapa sira hah, pemuda endi, wis bosen urip tah, eh pemuda Iin Tarminih kuh anake Hj. Dariyah wong sing paling dihormati"

(Babak 2, adegan 2)

Cerita ini menjadi sedikit menegangkang karena ocehan dari $\mathrm{Hj}$. Dariyah yang murka melihat keduanya sedang bermesrahan. Iin pun berusaha untuk menjelaskan, tetapi Iin merasa jika ia jelaskan pun tidak akan menyelesaikan masalah ini. Hal tersebut dibuktikan pada penggalan dari naskah drama berikut.

Iin :"Mi, iiiih mimi"

Dariyah :"Apa sih In, apa sih sirane plarak plorok bae matane, ora terima tah demenane tak sewoti, sirane ora terima tak demenane tak poyoki kuh" (Babak 3, adegan 3)

Hj. Dariyah marah bukan hanya karena melihat mereka berdua sedang berpacaran tetapi juga karena Iin telah berbohong, alasan keluar rumah untuk merobat ke dokter tetapi Iin malah bertemu dengan seorang pemuda di pinggir jalan.

\section{4) Hasil Analisis Tahap Penyelesaian}

Tahap

denouement

(penyelesaian) adalah permasalahan yang memuncak di dalam suatu cerita 
mulai menurun di tahap ini. Dalam tahap ini, sang tokoh mulai mengetahui cara mengatasi konflik yang tengah dia hadapi. Ketegangan yang dialami oleh pembaca atau penonton pun menurun ditahap ini. Ketegangan tersebut pelahan berubah menjadi kekaguman. Hal itu terjadi karena para pembaca atau penonton terkesima karena sang tokoh berhasil menyelesaikan masalah yang tengah dia hadapi dengan cara yang tak terduga. Tahap ini terlihat jelas bahwa Iin mampu menyelesaikan permasalahnya. Dia mengatakan ke Hj. Dariyah bahwa seseorang yang sedang bersamanya itu adalah bukan pacarnya tetapi seorang dokter. Iin terpaksa berbohong mengatakan hel tersebut supaya $\mathrm{Hj}$. Dariyah berhenti memahari Yoyo. Hal tersebut dibuktikan pada penggalan dari naskah drama berikut.

Iin :"Mi, mimi kuh due dedeleng beli sih mi, mi kuen kuh Dudu wong sembarangan kunuh mi,

Dariyah :"sapa sih kuene?

Dukun tah kuene,wong gedean tah

kuene kuh, ora wedi, tidak takut wewarah ya nang ning bapak tuane ira kon mene ya nang"

Iin :'Mi kuen kuh Pak

Dokter kunuh mi"

$\begin{array}{ll}\text { Dariyah } & \text { :"Pak Dokter?" } \\ \text { Iin } & : \text { Enggih" } \\ \text { Dariyah } & \text { :"Dokter?" } \\ \text { Iin } & \text { :"Kuh delengen gawa } \\ \text { tas ning jerone } & \text { kuh isine dom } \\ & \text { mlulu kunuh mi" }\end{array}$

Dariyah : :'Sira sih meneng bae Iin" (Babak 3, adegan 3)

Permaslaahan berangsur-angsur selesai ketika Hj. Dariyah mempercayai kalau seseorang yang sedang bersama Iin itu adalah dokter, dan bekal nasi yang dibawa Yoyo adalah peralatan dokter. Hal tersebut dibuktikan pada penggalan dari naskah drama berikut.

Iin : : Kang Yoyo, kang Yoyo pura-pura dadi Dokter ya kang"

Yoyo :"Dokter In"

Iin :"Iya kang,pander gah

mimi kan ora weruh ning dedeg pengadege kang Yoyo"

Yoyo : :Oooh iya In, ya wis iya In"

Iin : :Dereng mi,dau

dipriksane mawon"

Dariyah :"membe dipriksane bae? jage suntiken Pak Dok amber waras anake kula"

Yoyo : :Dereng wantun kula suntik $\mathrm{Bu}$,

Dariyah :"Apa sih Pak Dok"

Yoyo ;"Kedah ijin krihin, sebab kula sih dokter dokter spesialis"

Dariyah :"Oooh Dokter kusus" Yoyo : "Enggih bu, kusus

wadon"

Dariyah :"Dadi wong wadon bae sing disuntik? Ari sing tua keding wadon disuntik?"

Yoyo : :"Saged bu, asal masih bisa"

Dariyah :"Suntiken anake kula amber jage waras pak, dudu awite kuh priben sih In, kita mah bengen kuh ning puskesmas ngantri sampe jam-jaman kien sih an dokter lagi apa ning kebon kebon sabrang" (Babak 3, adegan 3) 


\section{SIMPULAN}

Strukturalisme genetik lahir dari seorang sosiolog Perancis, Lucien Goldmann. Kemunculannya disebabkan, adanya ketidakpuasan terhadap pendekatan strukturalisme, yang kajiannya hanya menitikberatkan pada unsur-unsur instrinsik tanpa memperhatikan unsur-unsur ekstrinsik karya sastra, sehingga karya sastra dianggap lepas dari konteks sosialnya. Strukturalisme genetik mencoba untuk memperbaiki kelemahan pendekatan strukturalisme, yaitu dengan memasukkan faktor genetik di dalam memahami karya sastra.

Struktur intrinsik naskah drama tarling “Dokter Palsu" Karya Hj. Dariyah sangat lengkap, tema digambarkan dengan gamblang. Begitu pula dengan alur atau plot. Penokohan/perwatakan tercermin dari berbagai dialog yang disajikan. Latar atau setting juga digambarkan sangat detail sehingga para pembaca dapat mengindrainya meski hanya lewat tulisan. Amanat atau makna yang terkandung dalam naskah drama ini adalah tentang percintaan anak muda yang tidak direstui oleh orang tua.

\section{DAFTAR PUSTAKA}

Arikunto, Suharsimi. 2006. Prosedur Penelitian, Suatu Pendekatan Praktek. Jakarta : Rineka Cipta.
Cohen. 1999. "The incantation of semar smiles: A tarling musical drama by Pepen Effendi".

Depdikbud. 2006. Kurikulum Tingkat Satuan Pendidikan Mata Pelajaran Bahasa dan Sastra Indonesia SLTP.Jakarta : Depdikbud.

Faruk, H.T. 2007.“Liminalitas dan Pengalaman Pascamodern". Cirebon: Kongres Bahasa Cirebon 1, 31 Juli-2 Agustus.

Harymawan, R. M. M. 1988. Dramaturgi. $\quad$ Bandung: $\mathrm{CV}$ Rosda.

Hasanudin. 2009. Drama Karya dalam Dua Dimensi. Bandung: Angkasa.

Hidayatullah, Riyan. 2015. "Seni Tarling dan Perkembangannya di Cirebon". FKIP Universitas lampung. Volume 1 Nomor 1, Juni 2015.

Kasim, Supali. 2002. "Migrasi Bunyi dari Gamelan ke Gitar Suling (Tarling)". Indramayu: Dewan Kesenian Indramayu.

Lexy J. Moleong. 2005. Metodologi Penelitian Kualitatif. Bandung: Rosdakarya.

Makmun, Syamsudin, Abin. 2004. Psikologi Pendidikan. Bandung: Rosda.

Nuryanto. 2014. Mari Bermain Drama (Kebahagiaan Sejati) Panduan Praktis Untuk Menjadi Aktor \& Aktris).Cirebon: Syariah Nurjati Press.

Riantiarno, N. 2011 Kitab Teater: Tanya Jawab Seputar Seni Pertunjukan. Jakarta: Gramedia Widia Sarana Indonesia, 
Salam, Chaerul. 2014. Tesis: Perlawanan Wanita terhadap Dominasi Partiarki dalam Teks Tarling Cirebon: Sebuah Analisis Semiotik Riffatere. Yogyakarta: Pascasarjana FIlsafat UGM.

Salim. 2015. “ Perkembangan dan Eksistensi Musik Tarling Cirebon. Jurnal of Arts Aducation. http://journal.unnes.ac.id/sju/indek s.php/catharsi diakses pada 20 Maret 2018.

Santosa, Puji. 2010. "Kearifan Budaya Lokal Sastra Lisan Kafoa". Jakarta: Badan Bahasa.

Saptono, Hariadi (ed). 2013. Warisan Budaya Wangsa Cerbon-Dermayu. Jakarta: Bentara Budaya.

Sugiyono. 2013. Metode Penelitian Pendidikan (Pendekatan Kualitatif, Kuantitatif, dan R\&D). Bandung: Alfabeta.

Sulistiji, dkk, 2001.Kamus Basa Indramayu. Indramayu: Dinas Pendidikan dan Kebudayaan Kabupaten Indramayu.
Sumardjo, Jakob. 2011. Pola Rasionalitas Budaya. Bandung: Kelir.

Supriatna, Adi dkk. 2016. "Upaya Pelestarian Musik Tarling Cirebon Studi Kasus pada Group Tarling Putra Sangkala Pimpinan Bapak Askadi". Thesis: Fakultas Seni dan Sastra.

Suratno, Siti Chamamah dan Chairul Salam. 2005. "Perlawanan Wanita Terhadap Dominasi Patriarki dalam Teks Tarling Cirebon: Sebuah Analisis Semiotik Riffatere. Yogyakarta: Humanika, 18/2, April 2018.

Suroso. 2015. Drama Teori dan Praktik Pementasan. Yogyakarta: Almatera.

Waluyo, Herman J. 2001. Drama Teori dan Pengajarannya. Yogyakarta: Hanindita Graha Widya.

Waluyo. 2006. Drama : Naskah, Pementasan, dan Pengajarannya. Cetakan 1. Surakarta: LPP, UNS Press 